\title{
Climate History of Asia (excluding China)
}

\author{
George C.D. Adamson ${ }^{\mathrm{a}}$ and David J. Nash ${ }^{\mathrm{b}, \mathrm{c}}$
}

Department of Geography, King's College London, Strand, London WC2R 2LS, UK

b School of Environment and Technology, University of Brighton, Brighton BN2 4GJ, UK

c School of Geography, Archaeology and Environmental Studies, University of the Witwatersrand, Private Bag 3, Wits 2050, South Africa

\section{Introduction}

As the largest landmass on Earth, the climatic history of Asia is of paramount importance. However, with the exception of China \{see Hao, this volume\}, research on the historical climatology of the continent remains in its infancy. Instrumental observation of weather in Asia began earlier than in many other parts of the world. In Siberia, observations date back to the formation of the Russian Central Physical Observatory in 1849 (Fleming 1988), while the genesis of the Japanese Meteorological Agency began with the founding of the Tokyo Meteorological Observatory in 1875. Systematic meteorological observation in India and Indonesia began shortly after the establishment in 1854 of national meteorological services in the UK and Netherlands, the colonial countries who then governed these regions. The Magnetisch en

Meteorologisch Observatorium in Batavia (Jakarta) was established in 1866, and the Indian Meteorological Department in 1875.

Reconstruction of climate for periods prior to the mid-19th century using documentary sources is only just commencing, although it is further advanced in Japan than in other regions of the continent (excluding China). Reconstructions using tree rings are common in the Himalayas, the Mongolian Steppes, northern Japan, and parts of Siberia. Coverage in tropical regions is much weaker due to the general absence of trees producing annual growth rings, although researchers have begun to derive climatic data from teak species (Tectona grandis) (e.g., Cook et al. 2010).

As the climate of Asia is extremely diverse-ranging from subarctic in Siberia (Df in the Köppen classification) to tropical rainforest in Indonesia (Af) - the continent will be divided into five regions for the purposes of this chapter. These are Arabia and West Asia; the Indian Subcontinent; Japan and Korea; Southeast Asia and Indonesia; and Siberia and Central Asia.

\section{Arabia and West Asia}

The documentary record of the Islamic world has been identified as a potentially fruitful source of historical climate information. Arabic (and other) language documents have been used substantially for information on historical astronomical occurrences (see Domínguez-Castro et al. 2012 and references therein). However, climate reconstruction has as yet been either preliminary (Grotzfeld 1991, 1995, Bulliet 2009, Weintritt 2009, Vogt et al. 2011, Domínguez-Castro et al. 2012) or focused on the Iberian peninsula (de Miguel 1988, Domínguez-Castro et al. 2014). The documents available for climate reconstruction are predominantly ta'rikh (history) chronicles, which require careful interpretation for climatic information. Moreover, many have been lost, existing now only in copy or abridged format (Domínguez-Castro et al. 2014). (On North Africa and Nile Valley, see also \{Nicholson\} and \{Damodaran et al.\} in this volume.) 
Nevertheless, some reconstruction has been undertaken for the period 800-1500 $\mathrm{AD}$, notably for Iraq, Syria and Palestine. Using references to freezing conditions, Ricardo Domínguez-Castro and colleagues identified that the $10^{\text {th }}$ century AD in Iraq witnessed a greater frequency of cold winters than the $20^{\text {th }}$. Steffen Vogt and colleagues have further demonstrated that winters from 900-950 and 1020-1070 AD were particularly wet. At a more coarse resolution, using documents from the late Roman Empire, McCormick (2012) identified droughts in Palestine from 210-220 and 311-313 AD, a return to wetter conditions around $400 \mathrm{AD}$, and further droughts from 523-538 AD. Available information on the Arab world becomes more limited after $1500 \mathrm{AD}$, a reversal of the situation in most other part of the world. This is likely related to a shift in the focus of the chronicles from accounts of events to biographical data and anecdotes at the turn of the $16^{\text {th }}$ century (Grotzfeld 1995).

The climate history of Anatolia has received somewhat more attention than that of the Arab world. Several scholars have undertaken studies assembling and mapping historical references to climatic and meteorological events during Hellenistic and Roman times. ${ }^{1}$ Byzantine historians have compiled more extensive descriptions of climate (particularly extremes such as drought and freezing winters) from the $4^{\text {th }}-15^{\text {th }}$ centuries AD. Some researchers have recently begun to integrate those descriptions with archaeological finds as well as paleoenvironmental reconstructions, with the goal of formulating a more comprehensive interdisciplinary climate history of Byzantine Anatolia. So far this research has identified probable periods of colder drier climate during the $4^{\text {th }}-5^{\text {th }}$ and late $8^{\text {th }}-9^{\text {th }}$ centuries, and possibly warmer wetter climate during the $10^{\text {th }}$-early $11^{\text {th }}$ centuries (Telelis 2008; Haldon et al. 2014). The Ottoman period (ca.1300-1923AD) offers further potential for detailed documentary-based climate reconstruction, including, among other sources, numerous chronicles, travel narratives, records from the imperial archives in Istanbul, and European diplomatic dispatches. So far only a handful of studies have analyzed particular episodes in Ottoman climate history, including Sam White's (2011) study of drought, rebellion, and crisis during the late $16^{\text {th }}-17^{\text {th }}$ centuries.

\section{The Indian Subcontinent}

Substantial written information on the climate of the Indian subcontinent becomes available from around $1700 \mathrm{AD}$ onwards. This is predominantly due to the knowledgeproduction project of various European colonial and missionary groups, particularly the British East India Company (Grove 1998). In recent years, scholars have begun to explore the documentary record of the East India Company to reconstruct the historical intensity of the monsoon and extreme meteorological events. The earliest reconstructions derive from records of the Royal Danish Lutheran-Protestant Mission in Tranquebar, which date from 1710 (Walsh et al. 1999). In western India, the records of the East India Company have been used to reconstruct monsoon duration and intensity from 1780 to 1860 (Adamson and Nash 2013, 2014). These reconstructions have demonstrated a long-term change in the average date of monsoon onset (Figure XX.1),

\footnotetext{
${ }^{1}$ e.g., M. McCormick et al., "Geodatabase of Historical Evidence on Roman and Post-Roman Climate" (2012), https://docs.google.com/spreadsheets/d/1meoPMwiiVZ_buAYgasx5NBt7Gz3Ar9LJysco6npzEgY/edit
} 
and have been used to explore the long-term relationship between the Indian monsoon and the El Niño Southern Oscillation. Using a selection of personal diaries from early 19th-century Bombay, George Adamson (2014) has also demonstrated that monthly maximum temperatures were then around $5^{\circ} \mathrm{C}$ lower than today, likely a result of the urban heat-island effect.

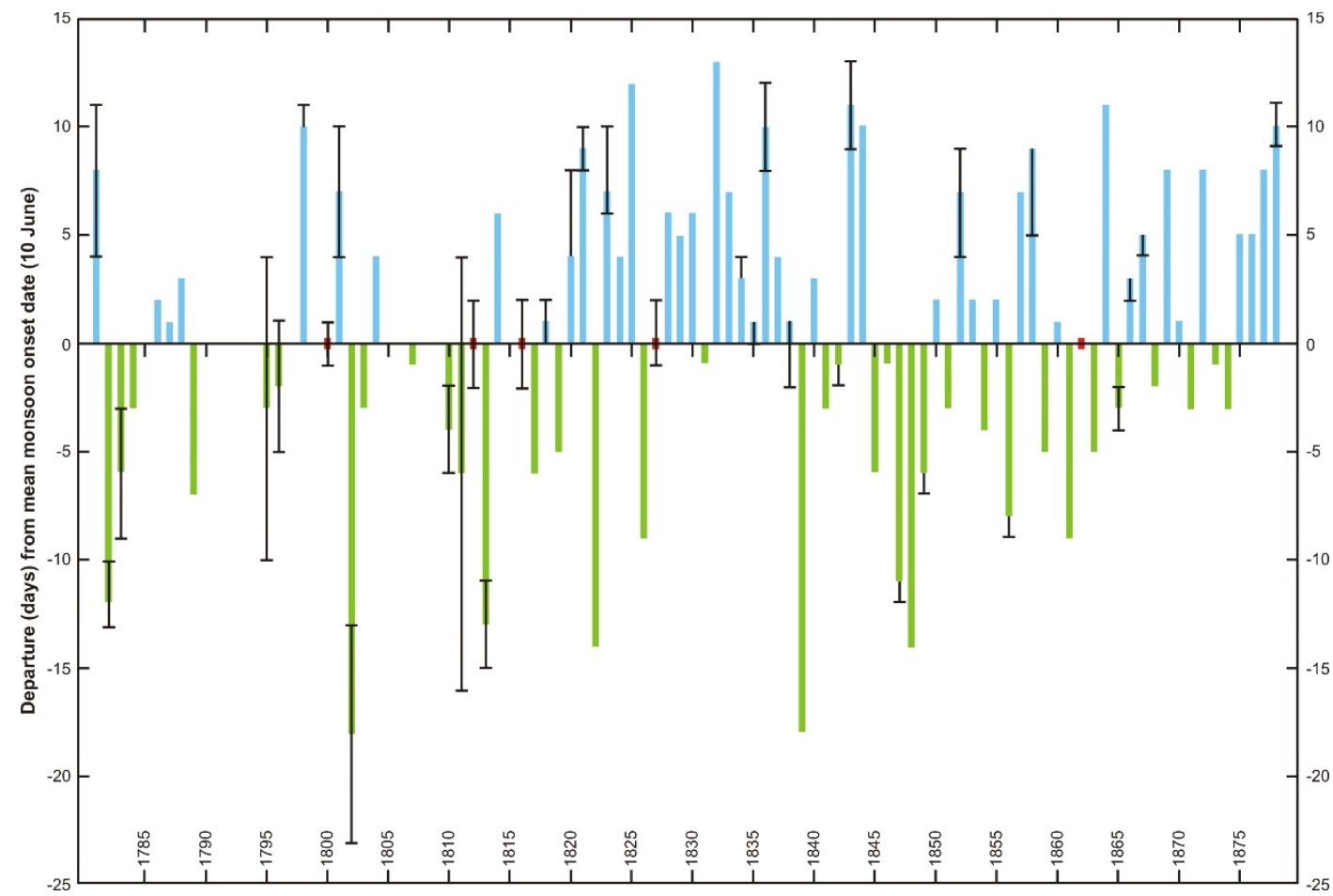

Figure XX.1: Reconstructed date of monsoon onset over Bombay for 1781-1878 (with error bars). Positive values indicate a later date of monsoon onset. From Adamson and Nash (2013).

For the pre-colonial period, G.B. Pant and colleagues (1993) reviewed a number of different types of written source material to uncover broad-scale monsoon variability for the past $\sim 1000$ years. This work revealed a 12-year drought between 1397 and 1408 and a random distribution of drought from 1600 AD onwards. Recorded drought before this date was relatively low, likely due to a lack of preserved documentary evidence.

\section{Japan and Korea}

Japan is one of the best-served regions for documentary climate reconstruction in Asia. Written evidence of climatic phenomena extends back to 55 AD (Ingram et al. 1981). Historical sources for climate reconstruction are reviewed in Takehiko Mikami's 2008 paper "Climatic Variations in Japan Reconstructed from Historical Documents" (Mikami 2008). The longest and possibly most robust record available is that of the "cherry blossom festivals," which coincided with the date of spring flowering of cherry trees at Kyoto, recorded regularly in diaries and chronicles. Flowering was found to correlate closely with average February-March temperatures, allowing springtime temperature to be reconstructed back to 801 AD (Aono and Omoto 1994, Aono and Kazui 2008, Aono and Saito 2010). Similar studies have been undertaken for Tokyo (Aono 2015). Likewise, the dates of ceremonies for the Omiwatari on Lake Suwa (a crack in the ice running the full length of the lake, caused by diurnal temperature variations) reach back to the $15^{\text {th }}$ 
century. The date of freezing was found to be highly correlated with mean DecemberJanuary temperatures, allowing reconstruction of these temperatures back to $1444 \mathrm{AD}$ (Mikami 2008). A large number of weather diaries from the $18^{\text {th }}$ century onwards have been digitised in the Historical Weather Database of Japan (see Mikami 2008, for further details), also enabling reconstruction of summer temperatures. These show a general increase in temperatures from around 1800 onwards, although this increase is not uniform (Mikami 2008). Other studies have used references to typhoons in documentary materials to reconstruct northwest Pacific typhoon frequency and tracks during the $19^{\text {th }}$ century (e.g. Grossman and Zaiki 2009).

Woo-Seok Kong and David Watts have undertaken a coarse-grained reconstruction of precipitation, frost, droughts and floods for Korea using documentary evidence (Kong and Watts 1992). This reconstruction demonstrates major cold phases from 1001 to $1400 \mathrm{AD}$, dry phases during 201-600, 701-900 and 1001-1300 AD, and humid phases from 400 to 500 and 1000 AD to the present. Famine seems to have been associated with the cold phases. Gyo-Ho Lim and Tae-Hyeon Shim additionally used the Annal of the Chosun-Dynasty to reconstruct extreme weather events from around 1400 $\mathrm{AD}$, indicating extreme droughts around 1440, 1600 and 1680, and wet periods around 1410, 1520 and 1660 (Lim and Shim 2002). The authors are unaware of any other such studies in Korea, although some may be available in the Korean language.

\section{Southeast Asia and Indonesia}

Southeast Asia and Indonesia have generally been understudied with regards to documentary climate analysis, although tree-ring reconstruction has been undertaken in parts of Java and Thailand. The authors are aware of no precipitation or temperature reconstructions, despite a wealth of documentary materials available from the records of the Dutch East India Company (VOC) and Dutch colonial government, as well as in local languages. More work has been done on cyclones (typhoons), particularly in the Philippines. Ricardo García-Herrera and colleagues (Ribera et al. 2005, García-Herrera et al. 2007, Ribera et al. 2008) reconstructed landfalling typhoons over the Philippines from 1566 to 1900, particularly using records compiled by the Spanish Jesuit Miguel Selga in 1935.

Research by historians not specifically designed to reconstruct climatic variability has uncovered evidence of extreme events, particularly drought. Victor Liberman has outlined evidence for drought in Burma, Cambodia and Vietnam during the $14^{\text {th }}$ century (Liberman 2011), a period that saw the concurrent decline of Pagan, Angkor and Dai Viet. Brendan Buckley and colleagues reviewed evidence for climate extremes in central Vietnam from the $13^{\text {th }}-18^{\text {th }}$ centuries using historical chronicles (Buckley et al. 2014). They note in particular a period of heavy climate-related mortality associated with the 17th-century "crisis" (also discussed by Reid (1990) and Boomgaard (2001)). In general such analysis has been only descriptive, and systematic climate reconstruction from documentary sources in the region remains elusive.

\section{Siberia and Central Asia}


Despite the availability of a number of sources of documentary evidence, most notably historical chronicles and Russian governmental documents and grade books, documentary-based climate reconstructions in Siberia and Central Asia also remain very limited. Much of the early work on the historical climatology of the former Soviet Union east of the Urals is reviewed by Borisenkov (1992, and references therein). Of particular note are the relatively mild climate conditions reconstructed in Siberia during the earlymid $17^{\text {th }}$ century - at the heart of the Little Ice Age-when conditions were sufficiently favourable to allow Russian vessels to sail from the Kola Peninsula to Chukotka in northeast Siberia and through the Bering Straits, opening up a trade route to the Pacific. The authors are aware, though, of no other significant studies.

\section{Conclusion}

Despite its size, the climate history of Asia (outside China) remains far less studied than Europe or North America. The chief source for historical climate patterns in much of the continent is the Monsoon Asia Drought Atlas, deriving predominatly from tree-rings (Cook et al. 2010). However, this work is contrained by the geographical spread of the growth-ring producing trees (mostly located in the Himalaya) and has been found to be unreliable in places (see Adamson and Nash 2014). Documentary climate reconstruction that has been undertaken has shown the importance of such approaches for understanding long-term climate variability, and the influence of climate on social change. Other work not specifically designed for climate reconstruction has demonstrated the potential of the written record in the region, and it is hoped that the climate history of the continent will continue to be revealed in the future.

\section{References}

Adamson, George C. D., 2014, Colonial private diaries and their potential for reconstructing historical climate in Bombay, 1799-1828, In: The East India Company and the Natural World, eds. Damodaran, Vinita, Winterbottom, Anna, Lester, Alan, Palgrave Macmillan, Chichester, pp. 102-127.

Adamson, George C. D., Nash, David J., 2013, Long-term variability in the date of monsoon onset over western India, Climate Dynamics.40, 2589-2603.

Adamson, George C. D., Nash, David J., 2014, Documentary reconstruction of monsoon rainfall variability over western India, 1781-1860, Climate Dynamics.42, 749-769.

Aono, Yasuyuki, 2015, Cherry blossom phenological data since the seventeenth century for Edo (Tokyo), Japan, and their application to estimation of March temperatures, International Journal of Biometeorology.59, 427-434.

Aono, Yasuyuki, Kazui, Keiko, 2008, Phenological data series of cherry tree flowering in Kyoto, Japan, and its application to reconstruction of springtime temperatures since the 9th century, International Journal of Climatology.28, 905-914.

Aono, Yasuyuki, Omoto, Yukio, 1994, Estimation of temperature at Kyoto since the 11th century using flowering data of cherry trees in old documents, Journal of Agricultural Meteorology.49, 263-272.

Aono, Yasuyuki, Saito, Shizuka, 2010, Clarifying springtime temperature reconstructions of the medieval period by gap-filling the cherry blossom phenological data series at Kyoto, Japan, International Journal of Biometeorology.54, 211-219. 
Boomgaard, Peter, 2001, Crisis mortality in Seventeenth Century Indonesia, In: Asian Population History, eds. Liu, Ts'ui-jung, Lee, James, Reher, David Sven, Saito, Osamu, Feng, Wang, Oxford University Press, New York, pp. 191-220.

Borisenkov, Ye P., 1992, Documentary evidence from the USSR, In: Climate since A.D. 1500, eds. Bradley, Raymond S., Jones, Philip D., Routledge, London, pp. 171-183.

Buckley, Brendan M., Fletcher, Roland, Wang, Shi-Yu Simon, Zottoli, Brian, Pottier, Christophe, 2014, Monsoon extremes and society over the past millenniusm on mainland Southeast Asia, Quaternary Science Reviews.95, 1-19.

Bulliet, Richard W., 2009, Cotton, Climate and Camels in Early Islamic Iran: a moment in world history. Columbia University Press, New York.

Cook, Edward R., Anchukaitis, Kevin J., Buckley, Brendan M., D'Arrigo, Rosanne D., Jacoby, Gordon C., Wright, William E., 2010, Asian monsoon failure and megadrought during the last millennium, Science.328, 486-489.

de Miguel, Juan C., 1988, Precipitaciones y sequias en el Valle del Guadalquivir en epoca Omeya, Anuario de Estudios Medievales.18, 55-76.

Domínguez-Castro, Fernando, de Miguel, Juan C., Vaquero, Jose M., Gallego, Maria C., Garcia-Herrera, Ricardo, 2014, Climatic potential of Islamic chronicles in Iberia: Extreme droughts (AD 711-1010), Holocene.24, 370-374.

Domínguez-Castro, Fernando, Vaquero, Jose M., Marin, Manuela, Cruz Gallego, Maria, Garcia-Herrera, Ricardo, 2012, How useful could Arabic documentary sources be for reconstructing past climate? , Weather.67, 76-82.

Fleming, James R., 1988, Historical Perspectives on Climate Change. Oxford University Press, New York.

García-Herrera, Ricardo, Ribera, Pedro, Hernández, Emiliano, Gimeno, Luis, 2007, Northwest Pacific typhoons documented by the Philippine Jesuits, 1566-1900, Journal of Geophysical Research, 112, DOI:10.1029/2006JD007370.

Grossman, Michael, Zaiki, Masumi, 2009, Reconstructing typhoons in Japan in the 1880s from documentary records, Weather.64, 315-322.

Grotzfeld, Heinz, 1991, Klimageschichte des Vorderen Orients 800-1800 A.D. nach arabischen Quellen, In: Historische Klimatologie in verschiedenen Klimazonen, eds. Glaser, Rüdiger, Walsh, Rory, Würzburger Geographische Arbeiten, pp. 21-24.

Grotzfeld, Heinz, 1995, Klimageschichte des Vorderen Orients 900-1900, Forschungsjournal der Westfälische Wilhelms-Universität Münster.1, 11-17.

Grove, Richard, 1998, The East India Company, the Raj and the El Niño: the critical role played by colonial scientists in establishing the mechanisms of global cliamte teleconnections 1770-1930, In: Nature and the Orient: the environmental history of South and Southeast Asia, eds. Grove, Richard, Damodaran, Vinita, Sangwan, Satpal, Oxford University Press, New delhi, pp. 123-154.

Haldon, John, Roberts, Neil, Izdebski, Adam, Fleitmann, Dominik, McCormick, Michael, Cassis, Marica, Doonan, Owen, Eastwood, Warren, Elton, Hugh, Ladstatter, Sabine, Manning, Sturt, Newhard, James, Nicoll, Kathleen, Telelis, Ioannes, Xoplaki, Elena, 2014, The climate and environment of Byzantine Anatolia: Integrating science, history, and archaeology, Journal of Interdisciplinary History.45, 113-161.

Kong, Woo-Seok, Watts, David P., 1992, A unique set of climatic data from Korea dating from $50 \mathrm{BC}$, and its vegetational implications, Global Ecology and Biogeography Letters.2, 133-138.Lieberman, Victor, 2011, Charter state collapse in Southeast Asia, ca. 1250-1400, as a problem in regional and world history, American Historical Review.116, 936-963. 
Lim, Gyo-Ho, Shim, Tae-Hyeon, 2002, The climate based on the Frequency of Meteorological phenomena in the annals of Chosun-Dynasty (in Korean with English abstract), Korean Meteorological Society.38, 343-354

McCormick, Michael, 2012, Climate Change during and after the Roman Empire: Reconstructing the Past from Scientific and Historical Evidence, Journal of Interdisciplinary History.XLIII, 169-220.

Mikami, Takehiko, 2008, Climatic variations in Japan reconstructed from historical documents, Weather.63, 190-193.

Pant, GB, Rupa Kumar, Koli, Sontakke, Neelima A., Borgaonkar, HP, 1993, Climate variability over India on century and longer time scales, In: Advances in tropical meteorology, eds. Keshavamurty, R.N., Joshi, Prakash C., Tata McGraw-Hill Publishing Company, New Delhi, pp. 71-84.

Reid, Anthony, 1990, The Seventeenth Century Crisis in Southeast Asia, Modern Asian Studies.24, 639-659.

Ribera, Pedro, Garcia-Herrera, Ricardo, Gimeno, Luis, 2008, Historical deadly typhoons in the Philippines, Weather.63, 194-199.

Ribera, Pedro, García-Herrera, Ricardo, Hernández, Emiliano, Gimeno, Luis, 2005, Typhoons in the Philippine Islands, 1901-1934, Climate Research.29, 85-90.

Telelis, Ioannis, 2008, Climatic fluctuations in the Eastern Mediterranean and the Middle East AD 300-1500 from Byzantine documentary and proxy physical paleoclimatic evidence - a comparison, Jahrbuch der österreichischen Byzantinistik.58, 167-208.

Vogt, Steffan, Glaser, Rüdiger, Luterbacher, Jurg, Riemann, Dirk, Al Dyab, Ghazi, Schönbein, Johannes, Garcia-Bustamente, Elena, 2011, Assessing the Medieval Climate Anomaly in the Middle East: The potential of Arabic documentary sources, PAGES News.19, 28-29.

Walsh, Rory P. D., Glaser, Rüdiger, Militzer, Stefan, 1999, The climate of Madras during the eighteenth century, International Journal of Climatology.19, 1025-1047.

Weintritt, Otfried, 2009, The floods of Baghdad. Cultural and technological responses, In: Natural disasters, cultural responses: case studies toward a global environmental history, eds. Mauch, Christof, Pfister, Christian Lexington Books, Lanham, pp. 165182.

White, Sam, 2011, The Climate of Rebellion in the Early Modern Ottoman Empire, Cambridge University Press, New York. 